\title{
Shape and Properties of Calcium Carbonate Obtained by Thermal Decomposition of Calcium Acetate
}

\author{
Osamu MACHINAGA and Junichi KASAI \\ (Department of Industrial Chemistry, College of Industrial Technology, Nihon University, ) \\ 1-2-1, Izumi-cho, Narashino-shi, Chiba 275
}

酢酸カルシウムの熱分解により生成する炭酸カルシウムの形状と特性

町長 治・笠井順一

(日本大学生産工学部工業化学科, 275 習志野市泉町 1-2-1)

\begin{abstract}
The production of calcium carbonate by the thermal decomposition of calcium acetate was tried. Calcium acetate changed into calcium carbonate (calcite structure) at a calcining temperature about $400^{\circ} \mathrm{C}$. The particles were large and tabular polycrystalline aggregates of 0. 3-1. $4 \mathrm{~mm}$ long and $0.06 \mathrm{~mm}$ across with low whiteness (under $40 \%$ ), large oil absorption (95-110 $\mathrm{ml} / 100 \mathrm{~g}$ ) and small specific surface area $\left(2-7 \mathrm{~m}^{2} / \mathrm{g}\right)$.

[Received May 10, 1988; Accepted March 16, 1989]
\end{abstract}

Key-words : Calcium carbonate, Large columnar shape, Tabular polycrystalline aggregates

\section{Introduction}

Precipitated calcium carbonates are used $^{1)}$ as fillers and modifiers in rubber, plastics and paper. There have been no reports, however, on the tabular crystal aggregates of calcium carbonate which are found in kaolin clay and talc. Particles larger than $5 \mu \mathrm{m}$ are found in heavy calcium carbonate and kaolin, but their particle sizes are not uniform because they are natural products. ${ }^{1,2)}$ Precipitated calcium carbonate does not contain particles larger than $5 \mu \mathrm{m}$.

In this work, calcium carbonate obtained by the thermal decomposition of calcium acetate was examined as a possible substitute for the present fillers in natural products.

\section{Experimental method}

Calcium acetate (guaranteed reagent, Kanto Chemical Co. ) was used. The X-ray diffraction pattern of the untreated sample is shown in Fig. 1. Three phases were detected by the X-ray diffraction analysis; relatively strong diffractions of monohydride ${ }^{3)}$ and relatively weak diffractions of anhydride ${ }^{4)}$ and hemihydride. ${ }^{5)}$ The weight loss in TG $(9.9 \%)$ from $102^{\circ}$ to $160^{\circ} \mathrm{C}$ which should be attributed to dehydration was close to the theoretical value $(10.23 \%)$ for the monohydride. Thermal analyses (DTA-TG) were performed in air and in nitrogen at a heating rate of $10^{\circ} \mathrm{C} / \mathrm{min}$ for a sample weighing $10 \mathrm{mg}$. The samples were calcined in air at a fixed temperature for 210 minutes in an electric furnace. The calcined samples were examined by X-ray diffraction, infrared absorp-

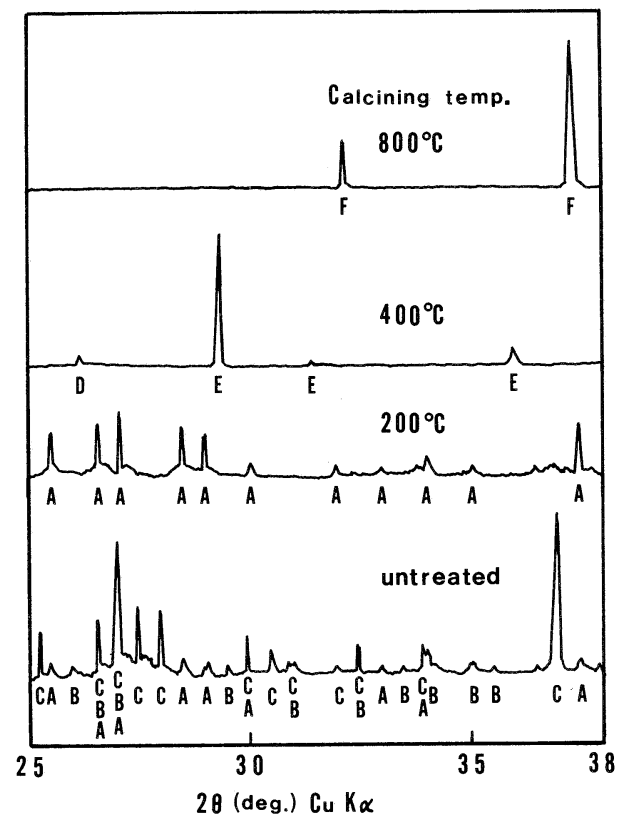

Fig. 1. Powder X-ray diffraction patterns of products obtained by calcining calcium acetate for $210 \mathrm{~min}$ in air. A : $\mathrm{Ca}\left(\mathrm{CH}_{3} \mathrm{COO}\right)_{2}, \mathrm{~B}: \mathrm{Ca}\left(\mathrm{CH}_{3} \mathrm{COO}\right)_{2} \cdot 0.5 \mathrm{H}_{2} \mathrm{O}$, $\mathrm{C}: \mathrm{Ca}\left(\mathrm{CH}_{3} \mathrm{COO}\right)_{2} \cdot \mathrm{H}_{2} \mathrm{O}, \mathrm{D}: \mathrm{C}$ (graphite), $\mathrm{E}: \mathrm{CaCO}_{3}$ (calcite), $\mathrm{F}: \mathrm{CaO}$

tion spectrum and scanning electron microscope. The following properties were measured: the specific surface area by nitrogen adsorption, the particle size distribution by phototransmission, Hunter whiteness by JIS P 8123, pH (10 wt \% suspension 5 minutes after the preparation), 
Munsell hue and oil absorption by JIS K 6223.

\section{Results}

\section{1 Thermal decomposition}

The results of thermal analyses are shown in Fig. 2. The X-ray diffraction patterns and the infrared spectra of the calcined samples are shown in Fig. 1 and Fig. 3 respectively. The DTA showed two peaks both in air and in nitrogen; one from $102^{\circ}$ to $160^{\circ} \mathrm{C}$ and the other from $178^{\circ}$ to $198^{\circ} \mathrm{C}$. The $\mathrm{TG}$ also indicated a two-step weight reduction $: 7.4 \%$ then $2.5 \%, 9.9 \%$ in total. No change was observed in the X-ray diffraction patterns for the samples calcined at $100^{\circ} \mathrm{C}$. Only the strong diffraction of the anhydride ${ }^{4)}$ was observed for the samples calcined at $200^{\circ} \mathrm{C}$ by which the dehydration was expected to complete.

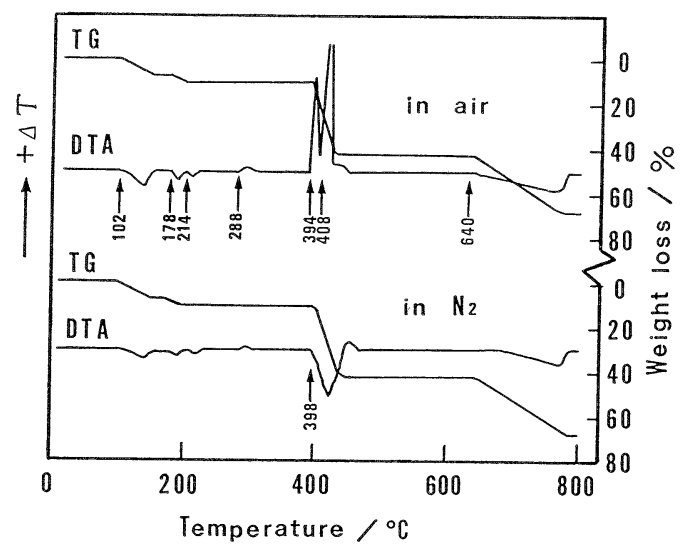

Fig. 2. DTA and TG of calcium acetate.

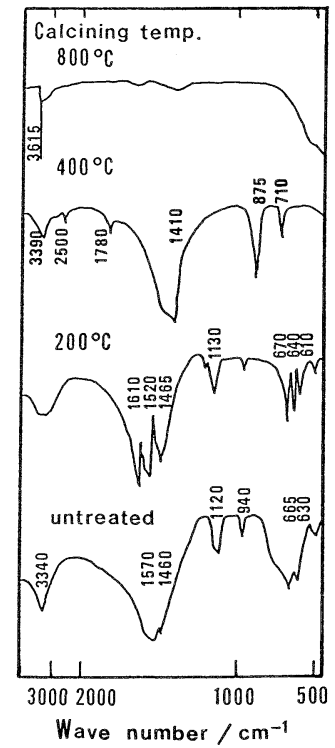

Fig. 3. Infrared absorption spectra of products obtained by calcining calcium acetate for $210 \mathrm{~min}$ in air.
As the calcination temperature rose to $200^{\circ} \mathrm{C}$, the absorption band of the IR spectrum split $\left(1450-1630 \mathrm{~cm}^{-1}\right.$ and $\left.600-680 \mathrm{~cm}^{-1}\right)$. The DTA showed two weak peaks without weight change which were not clarified in the present work; an endothermic peak from $214^{\circ} \mathrm{C}$ and an exothermic peak from $288^{\circ} \mathrm{C}$. The DTA in nitrogen showed one endothermic peak from $398^{\circ} \mathrm{C}$. This was tentatively attributed to the evolution of acetone for the following reasons: (1) Weight loss in TG $(31.9 \%)$ approximately agreed with the theoretical value $(33.08 \%)$ from calcium acetate to acetone and calcium carbonate. (2) Acetone was once obtained industrially by dry distillation of calcium acetate. ( 3 ) The evolution of acetone was experimentally examined by Wada et al. ${ }^{6)}$ V. I. Yakerson reported ${ }^{7)}$ the evolution of acetone for the similar compound (magnesium acetate).

One exothermic peak was observed from $390^{\circ} \mathrm{C}$ for a small amount of sample $(1.2 \mathrm{mg})$. The exothermic reaction was tentatively attributed to the combustion of acetone. The DTA in air (Fig. 2) showed two large consecutive exothermic peaks from $394^{\circ}$ and $408^{\circ} \mathrm{C}$ for a large amount of specimen $(10 \mathrm{mg})$. The peak splitting was interpreted as being due to insufficient oxygen supply. Similar phenomena were seen in a macroanalysis performed on the decomposition of calcium oxalate. ${ }^{8)}$

For the sample calcined at $400^{\circ} \mathrm{C}$, the X-ray diffraction pattern of calcite ${ }^{9)}$ was observed with a weak peak which suggests the existence of carbon (graphite). ${ }^{10)}$

The IR spectrum of calcite was observed for the sample calcined at $400^{\circ} \mathrm{C}$; a strong absorption at 1405 to $1470 \mathrm{~cm}^{-1}$, which is peculiar to the carbonate group and two additional absorptions ${ }^{11)}$ at $875 \mathrm{~cm}^{-1}$ and $710 \mathrm{~cm}^{-1}$. A weight loss in $T G$ $(25.6 \%)$ with an endothermic peak from $640^{\circ} \mathrm{C}$ should be attributed to the decomposition of calcium carbonate (theoretical value : $25.56 \%$ ). When the calcination temperature reached $700{ }^{\circ} \mathrm{C}$ or higher, the number of calcium oxide peaks among the calcium carbonate peaks gradually increased. Only the diffraction pattern for calcium oxide was observed for a specimen calcined at $800^{\circ} \mathrm{C}$. The sample calcined at $800^{\circ} \mathrm{C}$ showed a characteristic absorption band of divalent oxides near $400 \mathrm{~cm}^{-1}$ and a strong absorption band due to stretching vibration of free $\mathrm{OH}$ radical at $3615 \mathrm{~cm}^{-1}$.

\subsection{Scanning electron microscope observa- tion}

SEM photographs of the calcined specimens were shown in Fig.4. The untreated calcium acetate consisted of bulk transparent columnar 
particles (Fig. 4 (a)) $0.09-0.45 \mathrm{~mm}$ across and $0.4-3.0 \mathrm{~mm}$ long, which were like needle crystals. When heated at $100^{\circ} \mathrm{C}$, these particles became thin needle crystals of about $1 \mu \mathrm{m}$ (Fgi. 4 (b)). At the higher temperature $\left(350^{\circ} \mathrm{C}\right)$, cracks occurred on the surfaces of the needle crystals which then changed into tabular particles through aggregation (Fig. 4 (c)). The sizes of the tabular crystals were $4-20 \mu \mathrm{m}$ in width and $0.5-2 \mu \mathrm{m}$ in thickness. The outer shell maintained the shape of the original calcium acetate;the aggregates of
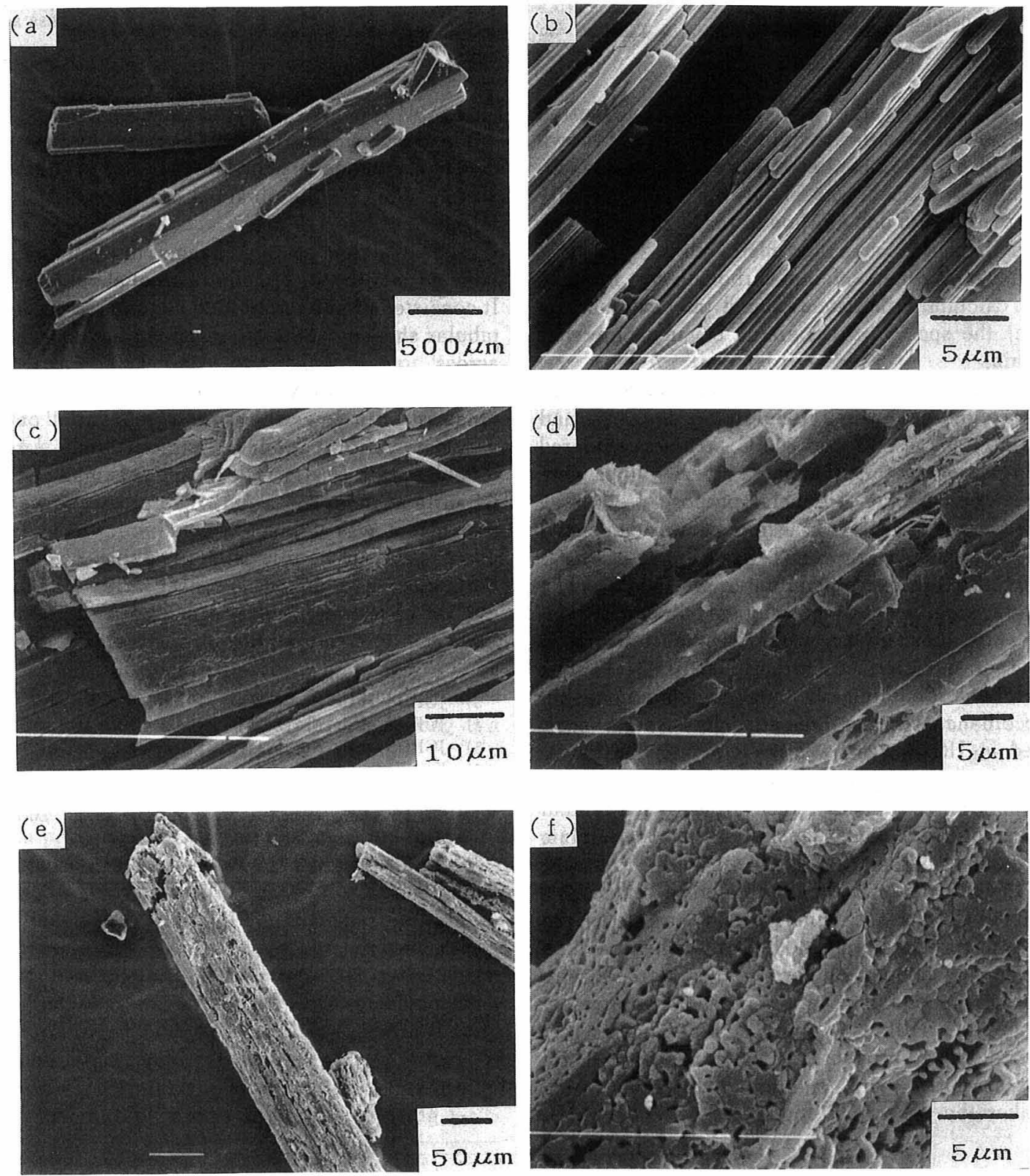

Fig. 4. Scanning electron micrographs of untreated and heat-treated calcium acetate. (a) untreated, (b) at $100^{\circ} \mathrm{C}$, (c) at $350{ }^{\circ} \mathrm{C}$, (d) and (e) at $450^{\circ} \mathrm{C}$, (f) at $700^{\circ} \mathrm{C}$ 


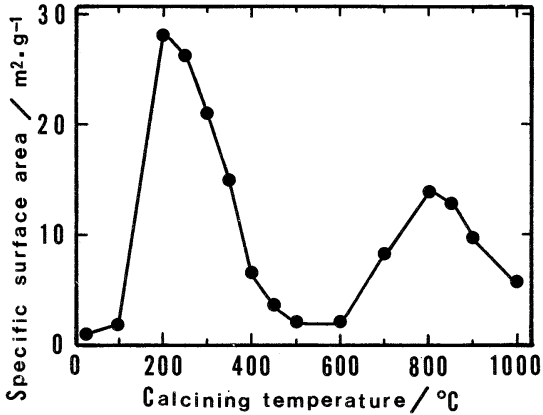

Fig. 5. Relation between the surface area and calcining temperature of calcium acetate.

The relationship between the calcination temperature and the specific surface area is shown in Fig. 5. The specific surface area of the untreated specimen was about $1 \mathrm{~m}^{2} / \mathrm{g}$; it rapidly increased with dehydration to reach $28 \mathrm{~m}^{2} / \mathrm{g}$. The specific surface area then decreased to $2-7 \mathrm{~m}^{2} / \mathrm{g}$ at $400^{\circ}-600^{\circ} \mathrm{C}$ when calcium carbonate was formed. As calcium carbonate changed into calcium oxide, the specific surface area began to increase again.

Oil absorption of the calcium carbonate formed by calcination were $110 \mathrm{ml} / 100 \mathrm{~g}$ at $450^{\circ} \mathrm{C}$ and $95 \mathrm{ml} / 100 \mathrm{~g}$ at $500^{\circ}$ and $600^{\circ} \mathrm{C}$. When considered in relation to the surface area, these values were greater than that of general purpose product ${ }^{12)}$ the large amounts of oil absorption was demanded in the paper. ${ }^{13)}$

Figure 6 shows the Hunter whiteness. The average whiteness of the calcined calcium carbonate was about $40 \%$, which is much lower than that of the product currently available. ${ }^{12)}$ The color of this calcium carbonate, when indicated in accordance with the three attributes system specified in JIS Z 8721, was 6 YR 6/1, a light gray based on a very pale yellow containing a trace of red. The color may come from graphite and organic components remaining in the calcium carbonate.

The $\mathrm{pH}$ was 7.9 for the untreated specimen, 9.8 for the specimen calcined at $350^{\circ} \mathrm{C}, 9.1-9.5$ for the specimen calcined $400^{\circ}-600^{\circ} \mathrm{C}$ when calcium carbonate formed. These values agreed with those of precipitated calcium carbonate currently available $^{12)}(\mathrm{pH}=8.4-10.1)$. This suggests that the calcinated product from calcium acetate is not contaminated with calcium hydroxide which makes the $\mathrm{pH}$ values higher.

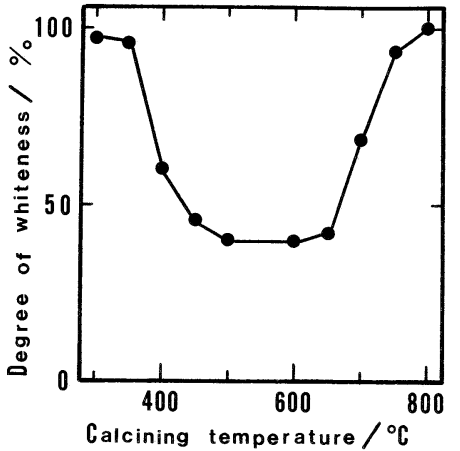

Fig. 6. Relation between the degree of whiteness and calcining temperature of calcium acetate.

\section{Conclusion}

The calcium carbonate was obtained by thermal decomposion of coarse needle particles of calcium acetate. The results obtained are summarized as follows :

(1) Calcium acetate changed to calcium carbonate (calcite) for $210 \mathrm{~min}$ in air at about $400^{\circ} \mathrm{C}$. It consisted of polycrystalline aggregates of large tabular shapes of $0.3-1.4 \mathrm{~mm}$ long and $0.06 \mathrm{~mm}$ across.

(2) The polycrystalline aggregates were obtained with low whiteness (gray based on a very pale yellow containing a trace of red), large oil absorption $(95-110 \mathrm{ml} / 100 \mathrm{~g})$ and small specific surface area $\left(2-7 \mathrm{~m}^{2} / \mathrm{g}\right)$. The $\mathrm{pH}$ of the water suspension was 9.1-9.5.

\section{References}

1) Y. Furusawa and T. Fujita, Gypsum \& Lime, 94, 15-24 (1968).

2) T. Sueno and S. Iwao, "Nendo To Sono Riyou", Asakura Shoten (1972) pp. 31-32.

3) JCPDS, File No. 30-221.

4) JCPDS, File No. 18-293.

5) JCPDS, File No. 19-199.

6) K. Wada, J. Yamashita and H. Hashimoto, Kogyo Kagaku Zasshi, 70, 311-15 (1967).

7) V.I. Yakerson and A.A. Fedorovskaya, Doklady Akademii Nauk SSSR, 140, 626-29 (1961).

8) A. Kamimura and Y. Fujinuma, "Introduction to Experimental Techniques for Thermal Analysis 2”, Kagaku Gijyutu Shya (1982) p. 223.

9) JCPDS, File No.5-586.

10) JCPDS, File No. 23-64.

11) K. Sato, F. Kurosawa and O. Kammori, Bull. Chem. Soc. Japan, 42, 3593-97 (1969).

12) Mining Soc. Limestone, "Sekkaiseki No Youto To Tokusei”, Sekkaiseki Kogyo Soc. (1986) p. 109.

13) F. Fujimura and T. Satake, Tech. Assoc. Pulp \& Paper Ind. , 40, 899-12 (1986). 